\title{
Calcium-Sensitive Uptake of Amino Acids by Human Placental Slices
}

\author{
PETER I. KARL, BENEDICT CHANG, AND STANLEY E. FISHER \\ Departments of Pediatrics and Research, North Shore University Hospital, Manhasset; and Cornell University \\ Medical College, New York, New York
}

\begin{abstract}
The placenta supplies many nutrients to the fetus, including amino acids by active transport. Although the exact regulatory mechanism is unknown, a few studies have suggested a role for calcium in amino acid transport. Therefore, we examined the relationship between calcium and amino acid uptake by term human placental slices. Calcium depletion of slices significantly reduced uptake of $\alpha$-aminoisobutyric (AIB), which is actively transported primarily by a sodium-dependent, carrier-mediated mechanism. Impairment of AIB uptake induced by calcium depletion was reversed by repletion with calcium but not with other divalent cations. In contrast, uptake of phenylalanine, which is transported primarily by a sodium-independent mechanism, was not affected by calcium depletion. Uptake of leucine and valine, which accumulate by both sodium-dependent and independent mechanisms, was partially affected by calcium depletion. Verapamil $(10 \mu \mathrm{M})$, an inhibitor of transmembrane calcium flux, significantly reduced AIB uptake. Trifluoperazine, a calmodulin antagonist, also inhibited AIB uptake. Analysis of AIB uptake kinetic constants for control and calcium-depleted slices showed no change in the diffusion constant, a $37 \%$ reduction in Vmax, and a 2-fold increase in $\mathrm{Km}$. The results indicate that calcium may be an important factor in the cellular regulation of active transport of amino acids. ( $\mathrm{Pe}$ diatr Res 23: 9-13, 1988)
\end{abstract}

\section{Abbreviations}

EBSS, Earle's balanced salt solution

AIB, ${ }^{14} \mathrm{C}$-amino isobutyric acid

Val, ${ }^{14} \mathrm{C}$-value

EGTA, ethyleneglycol-bis-(B-aminoethyl ether) $\mathbf{N}, \mathbf{N}^{\prime}$ tetraacetic acid

ICW, intracellular water

Kd, diffusion constant

$Y$, transport velocity

$\mathbf{R}$, ratio

Maternal to fetal transfer of nutrients by the placenta is critical to normal fetal growth. Among these nutrients are essential amino acids. The placenta actively transports neutral amino acids, maintaining a higher concentration in fetal blood than in maternal blood. Enders et al. (1) have demonstrated at least three neutral amino acid transport systems in human placental villous

Received July 2, 1987; accepted August 19, 1987.

Correspondence and reprint requests to Stanley E. Fisher, M.D., Boas-Marks Biomedical Science Research Center, North Shore University Hospital, Manhasset, VY 11030.

Supported in part by a grant from the NICHD (HD 17375). S.E.F. is the ecipient of a Research Scientist Development Award from the NIAAA (AA 00074). tissue, which correspond approximately to the A, L, and ASC systems described by Christensen and coworkers $(2,3)$. The A and ASC systems are known to be sodium dependent; the $\mathrm{L}$ system is sodium independent. In some cases, the transport systems have overlapping specificity. Although some of the characteristics of the transport mechanisms are characterized, the precise mechanisms for regulation of active transport for each system remain uncertain.

Early studies by Christensen (4) suggested that in vitro amino acid uptake by rat diaphragm may be calcium dependent. More recently, studies with isolated hepatocytes have indicated that glucagon stimulation of the A system is calcium sensitive (5). Since the placenta is a readily available source of human transport epithelium, we have examined the effect of tissue calcium depletion upon amino acid uptake by term human placental villous slices.

\section{MATERIALS AND METHODS}

EBSS with glucose and phenol red was obtained from Gibco Laboratories (Grand Island, NY); ${ }^{14} \mathrm{C}$-AIB, ${ }^{14} \mathrm{C}$-valine, ${ }^{14} \mathrm{C}$-leucine, ${ }^{14} \mathrm{C}$-phenylalanine, ${ }^{14} \mathrm{C}$-inulin from New England Nuclear (Boston, MA); nonradioactive amino acids, choline chloride, choline bicarbonate, trifluoperazine, EGTA, cycloheximide, and actinomycin D from Sigma Chemical Co (St. Louis, MO). Verapamil $\mathrm{HCl}$ was a gift from $\mathrm{Mr}$. T. B. Martinez, G. D. Searle \& Co. (Skokie, IL).

Term placentas were obtained and slices were prepared by a modification of the methods of Smith et al. (6), as described previously (7). Briefly, slices were prepared within $20 \mathrm{~min}$ of delivery, rinsed three times in ice cold physiologic saline, and incubated in EBSS, $\mathrm{pH} 7.4$, at $37^{\circ} \mathrm{C}$ in a Dubnoff metabolic shaking incubator. In all incubations the tissue to volume ratio was $10-20 \mathrm{mg} / \mathrm{ml}$ EBSS. In order to modify the tissue calcium content, slices were exposed to a series of incubations. Following the 30-min incubation in complete EBSS (preincubation phase), slices were depleted of calcium by a 30 minute incubation in calcium-free EBSS containing $2 \mathrm{mM}$ EGTA (depletion phase). Amino acid uptake (uptake phase) was determined after the depletion phase, in order to assess the effect of diminished tissue calcium. In some experiments, the depletion phase was followed by incubation in calcium ( $1.8 \mathrm{mM})$-containing EBSS for $60 \mathrm{~min}$ (repletion phase), to restore tissue calcium. This repletion phase was inserted into the protocol prior to uptake in order to assess reversibility. Repletion with the ionophore A23187 offered no advantage (in terms of restoration of AIB uptake) over $60 \mathrm{~min}$ repletion without ionophore. Therefore, A23187 was not used in this phase of the protocol.

To evaluate the effectiveness of the depletion phase on decreasing total tissue calcium, slices were incubated in calcium-free EBSS, containing $2 \mathrm{mM}$ EGTA for $30 \mathrm{~min}$. Following incubation, slices were washed in calcium-free EBSS, homogenized, extracted with $6 \mathrm{~N}$ nitric acid at $90^{\circ} \mathrm{C}$ for $60 \mathrm{~min}$, centrifuged at 
$3000 \times g$ for $10 \mathrm{~min}$, and the supernatant utilized for measurement of total tissue calcium. The calcium concentration in both the acid extract supernatant was determined by atomic absorption flame spectrometry, using a Perkin-Elmer model 3058 spectrometer.

Accumulation of amino acid during the uptake phase was measured by incubating two slices each in sealed 25-ml flasks, containing $5 \mathrm{ml}$ of aerated $\left(95 \% \mathrm{O}_{2} / 5 \% \mathrm{CO}_{2}\right)$ EBSS and radiolabeled amino acid, under an atmosphere of $95 \% \mathrm{O}_{2} / 5 \% \mathrm{CO}_{2}$. Final amino acid concentrations in the medium were $125 \mu \mathrm{M}$ for AIB and $50 \mu \mathrm{M}$ for leucine, valine, and phenylalanine. At the end of the uptake phase, slices were pressure-blotted, weighed and processed to determine radioactivity per $\mathrm{ml} \mathrm{ICW} \mathrm{(8).} \mathrm{Extra-}$ cellular water was calculated from the ${ }^{14} \mathrm{C}$-inulin space in separate slices for each placenta (7). Transport activity was expressed as the $\mathrm{R}$ of the concentration of ${ }^{14} \mathrm{C}$-amino acid in the intracellular water to that in the medium (8).

In some experiments, verapamil $(0.1-50 \mu \mathrm{M})$ was added to either the repletion and/or uptake phases (Table 1) to study the effect of blocking transmembrane calcium flux. In other experiments, trifluoperazine $(10-100 \mu \mathrm{M})$ was added to the uptake phase to assess the effect of calmodulin blockade upon amino acid transport. Experiments designed to determine the role of new protein synthesis utilized cycloheximide $(1 \mu \mathrm{g} / \mathrm{ml})$ and actinomycin $\mathrm{D}(1 \mu \mathrm{g} / \mathrm{ml})$ in the repletion and uptake phases.

To study the effect of calcium depletion on sodium-independent transport, amino acid uptake was carried out in sodium-free EBSS. Sodium was replaced with equimolar choline; otherwise the tissue handling procedure was unaltered.

For determination of the AIB Kd and Y, the method of Akedo and Christensen (9), as described by Smith (10), was used. The other AIB transport kinetic parameters, $\mathrm{Km}$ and Vmax, were determined using the Woolf-Augustinsson-Hofstee plot (20).

Data are expressed as mean \pm SEM and analyzed by the $t$ test for paired data or by analysis of variance. Differences between group means were considered significant for $p<0.05$.

\section{RESULTS}

Effect of EGTA treatment on tissue calcium and fluid distribution. EGTA treatment reduced the total tissue calcium by approximately $50 \%$ similar to that reported for rat hepatocyte studies (11): control $=5.98 \pm 0.51 \mathrm{mg} / \mathrm{g}$ tissue; calcium depleted $=3.37 \pm 0.45 \mathrm{mg} / \mathrm{g}$ tissue. Subsequent incubation in calcium containing-EBSS for $60 \mathrm{~min}$ restored tissue calcium to $85-90 \%$ of control levels. Calcium depletion by EGTA treatment had no effect on total, ICW, or extracellular water concentrations (Table 1).

Effect of tissue calcium depletion upon amino acid uptake. Tissue calcium depletion significantly reduced AIB uptake over a 60-min uptake time course (Figs. 1 and 2). This effect was reversed when tissue was repleted with calcium prior to Uptake (Fig. 1). Active accumulation of AIB into placental slices was temperature sensitive: after incubation for $60 \mathrm{~min}$ at $4^{\circ} \mathrm{C}$, the $\mathrm{R}$

Table 1. Effect of calcium depletion on fluid distribution*

\begin{tabular}{cccc}
\hline & \multicolumn{3}{c}{ Percent wet wt } \\
\cline { 2 - 4 } Treatment & ECW & ICW & TW \\
\hline$+\mathrm{Ca}$ & $37.9 \pm 0.9$ & $43.2 \pm 1.1$ & $81.2 \pm 0.6$ \\
$-\mathrm{Ca}$ & $39.1 \pm 1.5$ & $43.3 \pm 1.6$ & $82.5 \pm 0.6$ \\
\hline
\end{tabular}

* Placental slices were incubated in either control EBSS or calciumfree EBSS containing $2 \mathrm{mM}$ EGTA for $30 \mathrm{~min}$ (depletion phase). Following the repletion phase, slices were further incubated for $60 \mathrm{~min}$ with ${ }^{14} \mathrm{C}$-inulin. Slices were rinsed in calcium-free EBSS, pressure-blotted, weighed, and processed as described in the text to determine ${ }^{14} \mathrm{C}$-inulin space. Values represent means $\pm \mathrm{SE}$ of eight experiments totaling 48 slices. ECW, extracellular water; TW = total water.

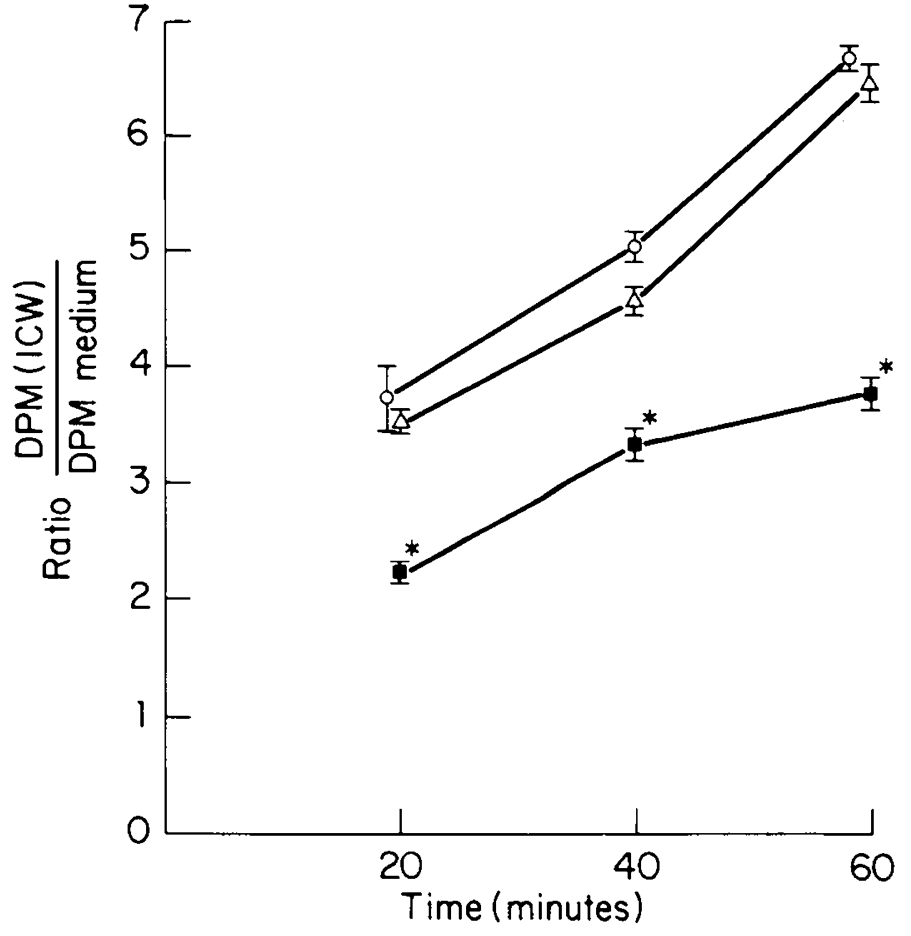

Fig. 1. Effect of $\mathrm{Ca}^{++}$depletion and repletion on AIB uptake by term human placental slices. Slices were incubated as described in Table 1. A 60-min AIB uptake was determined for control $(O), \mathrm{Ca}^{++}$depleted $(\mathbf{\square})$, and $\mathrm{Ca}^{++}$Repleted $(\triangle)$ slices. Values are mean $\mathrm{R} \pm \mathrm{SEM}$ from five to nine experiments totaling $25-45$ slices. ${ }^{*} p<0.01$. (analysis of variance).

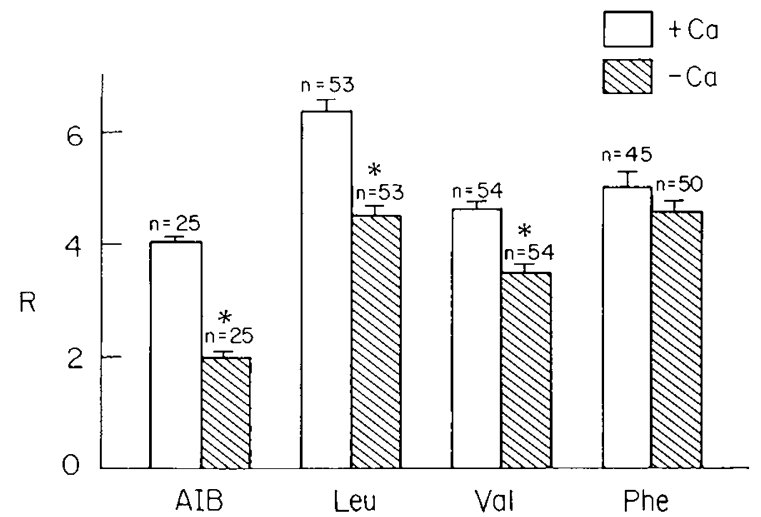

Fig. 2. Effect of $\mathrm{Ca}^{++}$depletion on amino acid uptake by human placental slices in the presence of sodium. Amino acid uptake by either control or $\mathrm{Ca}^{++}$-depleted slices was carried out in the presence of sodium. ${ }^{*} p<0.01 . n=$ number of observations.

was $0.75 \pm 0.03$. This suggest that nonspecific binding does not contribute to an $\mathrm{R}>1$.

Tissue calcium depletion also reduced uptake of leucine and valine (Fig. 2). However, the percentage of uptake which was calcium sensitive was smaller than that seen with AIB. Human placental slice uptake of phenylalanine, on the other hand, was unaffected by reduced tissue calcium.

Effect of calcium depletion upon sodium-independent amino acid uptake. When sodium was replaced with choline in the incubation medium, active uptake of AIB was eliminated, as indicated by an $\mathrm{R}$ of essentially 1 (Fig. 3). The small amount of AIB which did enter the tissue, presumably due to the binding and diffusion, was unaffected by calcium depletion (Fig. 3). 


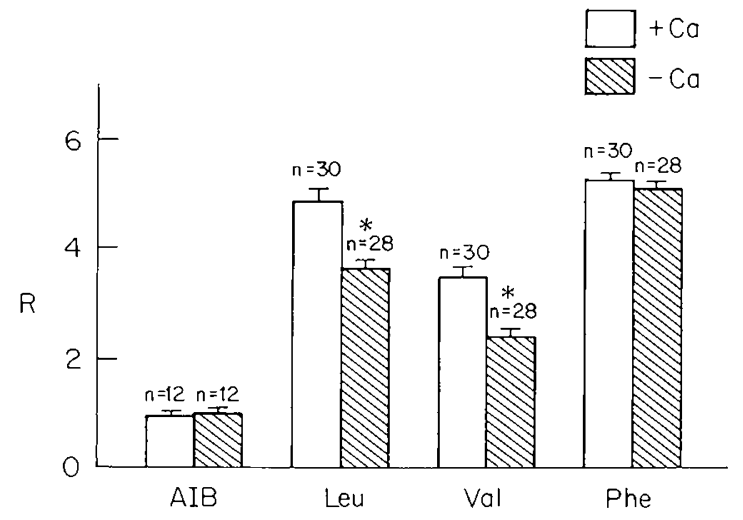

Fig. 3. Effect of $\mathrm{Ca}^{++}$depletion on amino acid uptake by human placental slices in the absence of sodium. Amino acid uptake by either control or $\mathrm{Ca}^{++}$-Depleted slices was carried out in the absence of sodium. Sodium was replaced by choline. ${ }^{*} p<0.01 . n=$ number of observations

However, active uptake of other neutral amino acids, leucine and valine, were only partially reduced by the absence of sodium in the medium. Therefore, uptake of these amino acids were both sodium-dependent and sodium-independent. Approximately $24 \%$ of leucine and $25 \%$ of valine uptake is sodiumdependent in human placental slices. Phenylalanine, an aromatic amino acid that has high selectivity for the $\mathrm{L}$ system in other tissues, was totally sodium independent.

Depletion of tissue calcium reduced both the sodium-dependent and sodium-independent uptake of leucine and valine (Figs. 2 and 3). However, phenylalanine uptake was unaffected by calcium depletion in the presence or absence of sodium.

Specificity of calcium ion effect on AIB uptake. In order to examine the effect of calcium depletion on amino acid uptake, AIB uptake was selected as a model. The effect of calcium appears to be specific, in that substitution of other divalent cations, namely strontium or barium $(1.8 \mathrm{mM})$, failed to induce recovery when used in the repletion phase:calcium repleted $\mathrm{R}=5.63 \pm$ 0.46 ; calcium depleted $=2.89 \pm 0.12$; strontium repleted $\mathrm{R}=$ $3.20 \pm 0.11$; barium repleted $=2.43 \pm 0.11$.

Effect of verapamil upon AIB uptake. Verapamil, an inhibitor of transmembrane calcium flux in some tissues, was used to estimate the effect of calcium entry blockade upon AIB uptake. When verapamil $(0.1,1$, and $10 \mu \mathrm{M})$ was included during the uptake phase there was a small but significant dose-dependent inhibition of AIB uptake (Table 2). Similarly, $50 \mu \mathrm{M}$ verapamil partially prevented the usual uptake restoration seen with calcium repletion: calcium repleted (control) $\mathrm{R}=5.88 \pm 0.35$; calcium depleted $\mathrm{R}=3.58 \pm 0.19$; calcium repleted + verapamil $\mathrm{R}=4.78 \pm 0.35$ ( $p<0.05$, compared to control or depleted)

Effect of trifluoperazine upon AIB uptake. Many intracellular calcium functions are modulated by the cytosolic calcium-binding protein, calmodulin. In order to assess a role for calmodulin in the regulation of AIB uptake, trifluoroperazine, a calmodulin blocker, was included during uptake phase. A dose-related (10$100 \mu \mathrm{M}$ ) inhibition of AIB uptake was found (Fig. 4) with a maximal inhibition by $50 \mu \mathrm{M}$.

Effect of cycloheximide and actinomycin $D$ upon AIB uptake. In the experiments described above, slices were treated for as long as $2 \mathrm{hr}$ before determination of amino acid uptake. Because this was sufficient time for new protein synthesis, the effect of calcium depletion upon amino acid uptake might have been due to an alteration in protein synthesis. When tissues was exposed to the protein synthesis inhibitors, cycloheximide or actinomycin $\mathrm{D}$, there was no effect on the calcium repletion effect (Table 3 ). Cycloheximide did reduce overall uptake, but the proportional recovery with the calcium repletion was unchanged.

Effect of calcium depletion upon AIB uptake kinetics. AIB uptake by calcium depleted and control slices was determined
Table 2. Inhibition of placental AIB uptake by verapamil*

\begin{tabular}{rl}
\hline Group & $\mathrm{R} \pm \mathrm{SEM}$ \\
\hline Control & $6.63 \pm 0.63$ \\
Verapamil & \\
$0.1 \mu \mathrm{M}$ & $6.59 \pm 0.55$ \\
$1.0 \mu \mathrm{M}$ & $5.92 \pm 0.56$ \\
$10.0 \mu \mathrm{M}$ & $5.62 \pm 0.37 \dagger$ \\
\hline
\end{tabular}

* In this experiment, slices were incubated with complete-EBSS through all phases and verapamil was present only during the $60 \mathrm{~min}$ AIB Uptake Phase. Values are mean $\mathrm{R} \pm$ SEM from six experiments (six placentas) totaling 30 slices per group.

$\dagger p<0.05$ (analysis of variance).

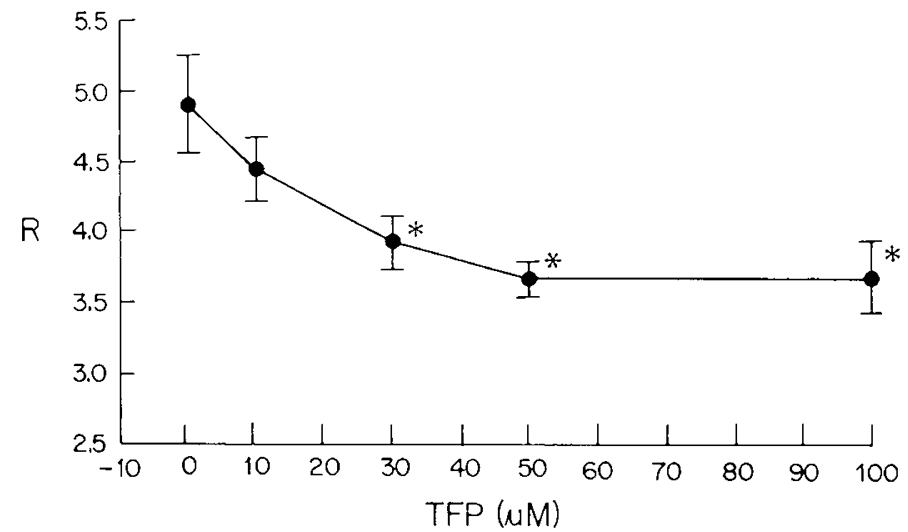

Fig. 4. Inhibition of AIB uptake by trifluoperazine (TFP). All slices were incubated as described in Table 1. TFP was added to repletion and uptake phases. ${ }^{*} p<0.01$ (analysis of variance).

by incubating tissue with 0.05 to $20.0 \mathrm{nM}{ }^{14} \mathrm{C}$-AIB for $20 \mathrm{~min}$. A representative plot of $R$ versus $1 / C$ (Fig. 5), from which $K d$ is derived, demonstrates that both lines approach the same $Y$ intercept at high AIB concentrations. Therefore $\mathrm{Kd}$ was not altered by calcium depletion. The mean value of $\mathrm{Kd}$ from four placentae is presented in Table 4. The Woolf-AugustinssonHofstee plot (Y versus Y/Co; Fig 6) indicate that both the Vmax (X-intercept) and $\mathrm{Km}$ (negative slope) have been altered by calcium depletion. Mean values for Vmax and $\mathrm{Km}$ (Table 4) show that calcium depletion caused a $37 \%$ decrease in the V $\max$ and a 2-fold increase in the $\mathrm{Km}$.

\section{DISCUSSION}

The result of this study demonstrate that tissue calcium depletion selectively reduces in vitro active uptake of amino acids such as AIB, leucine, and valine, while phenylalanine is unaffected. The observations were not due to changes in total water, extra cellular water, or ICW content. It was also not due to nonspecific cytotoxicity from EGTA treatment, as phenylalanine transport was unaffected and virtually complete recovery of AIB uptake occurred with calcium repletion.

Evidence for the findings being specific to calcium comes from the failure of other divalent cations to induce recovery following the repletion phase. If calcium depletion merely removed divalent cation blockade of sodium ion channels, recovery would not have been specific for calcium (12).

The specific role of calcium is further supported by the pharmacologic manipulations with verapamil and trifluoperazine. The former is considered to be a generalized blocker of transmembrane calcium flux (13). Accordingly, the presence of verapamil in the repletion and/or uptake phases reduced AIB uptake and partially prevented the usual recovery with repletion of calcium. The latter drug has, among other actions, the capacity to block calmodulin. In all tissues, intracellular calcium is par- 
Table 3. Effect of actinomycin $D$ and cycloheximide on $A I B$ uptake*

\begin{tabular}{lccc}
\hline & \multicolumn{3}{c}{$\mathrm{R} \pm \mathrm{SEM}$} \\
\cline { 2 - 4 } \multicolumn{1}{c}{ Group } & None & $\mathrm{Actinomycin}$ \\
\hline $\mathrm{Ca}^{++}$depleted & $2.51 \pm 0.11$ & $2.40 \pm 0.17$ & Cycloheximide \\
$\mathrm{Ca}^{++}$repleted & $3.92 \pm 0.24$ & $4.30 \pm 0.32$ & $3.08 \pm 0.11$ \\
Repleted as \% of depleted & 156 & 179 & 169 \\
\hline
\end{tabular}

*Actinomycin D $(1 \mu \mathrm{g} / \mathrm{ml})$ and cycloheximide $(1 \mu \mathrm{g} / \mathrm{ml})$ were added to the repletion and uptake phases.

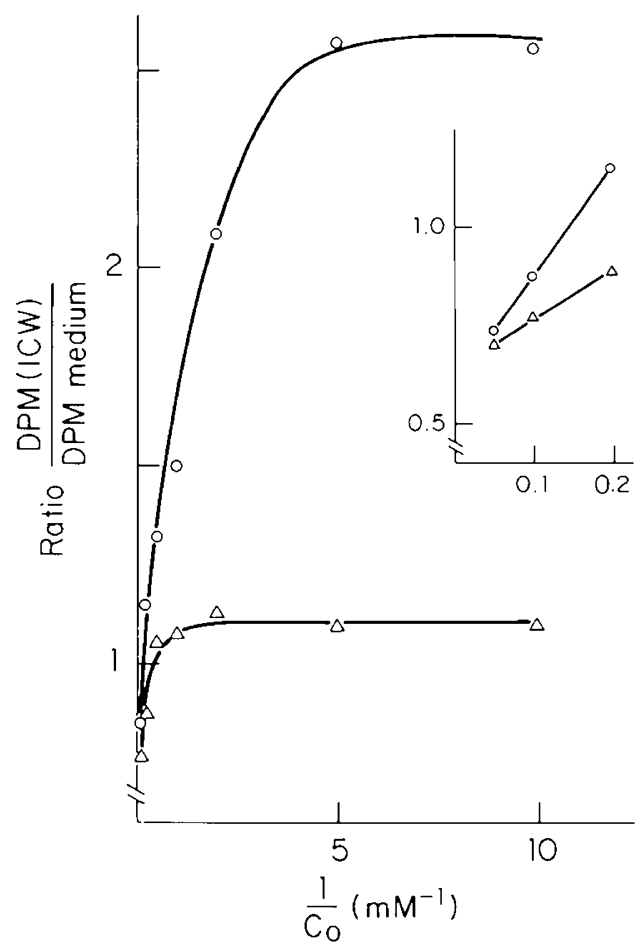

Fig. 5. Representative plot of $\mathrm{R}$ vs reciprocal of AIB concentration in medium $(1 / \mathrm{Co})$ for control $(\mathrm{O})$ and $\mathrm{Ca}^{++}$-depleted $(\Delta)$ groups. Inset is an expanded scale showing data for high AIB concentrations. These data show that the y-intercept is unaltered (inset), indicating no alteration in $\mathrm{Kd}$. At lower concentrations, such as $0.125 \mathrm{mM}$ AlB used for single concentration timed uptakes, the uptake ratio is constant within each treatment group.

titioned (14). In the cytosol, calmodulin binds calcium and is an important mediator of calcium sensitive cell functions (15). Inhibition of AIB uptake by trifluoperazine suggests that at least part of the sensitivity of amino acid uptake to calcium may be mediated through calmodulin. However, trifluoperazine may be altering other calcium-related cell functions: microtubules (16), calcium pump (17), and protein kinase $C$ (18).

The effect of calcium depletion on placental amino acid uptake suggests that calcium sensitivity may be an additional parameter for defining transport characteristics. We found that both the sodium-dependent and independent transport of leucine and valine are calcium sensitive. In contrast, phenylalanine uptake is sodium independent and is calcium insensitive. Finally, AIB was exclusively sodium dependent in our study. Its uptake was proportionally more sensitive to calcium depletion than the sodiumdependent uptake of either leucine or valine.

From the AIB uptake kinetic data, it appears that calcium depletion may have exerted its effect in more than one fashion. This is illustrated by alterations in apparent $\mathrm{Km}$ and Vmax.

In summary, we have observed that tissue calcium depletion

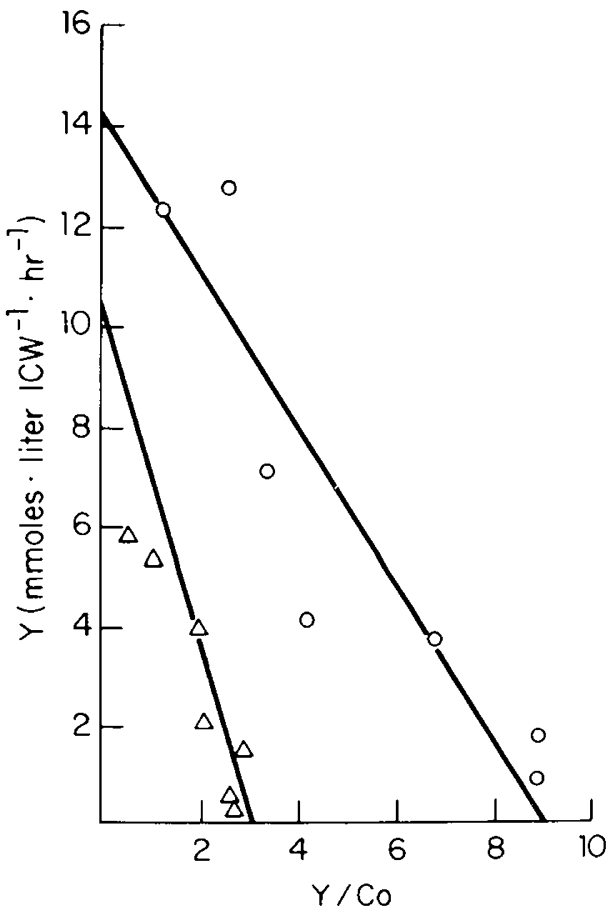

Fig. 6. Woolf-Augustinsson-Hofstee plot of AIB uptake [uptake velocity $(\mathrm{Y})$ vs ratio of $\mathrm{Y}$ to $\mathrm{AIB}$ concentration in medium $(\mathrm{Y} / \mathrm{CO})]$. Slices were incubated as described in Table 1. AIB uptake was determined during a 20-min uptake phase for control $(O)$ and $\mathrm{Ca}^{++}$depleted $(\triangle)$.

Table 4. Effect of $\mathrm{Ca}^{++}$depletion on AIB uptake kinetic constants* $^{*}$

\begin{tabular}{lccc}
\hline \multicolumn{1}{c}{ Group } & ${\mathrm{Kd}, \mathrm{h}^{-1}}$ & $\begin{array}{c}\text { Vmax, mmol } \\
\text { liter } \mathrm{ICW}^{-1} \mathrm{~h}^{-1}\end{array}$ & $\mathrm{Km}, \mathrm{mM}$ \\
\hline Control & $3.94 \pm 0.63$ & $9.54 \pm 1.70$ & $0.78 \pm 0.24$ \\
$\mathrm{Ca}^{++}$depleted & $3.69 \pm 0.50$ & $6.00 \pm 0.94 \dagger$ & $1.43 \pm 0.31 \dagger$ \\
\hline
\end{tabular}

* Slices were incubated through four phases as described in Table 1. AIB uptake was determined during a 20 -min uptake incubation period. Data represent mean \pm SEM from four experiments.

$\dagger p<0.05$

may help to further characterize amino acid transport in the human placenta. Uptake of AIB, found to be totally sodium dependent, is also strongly inhibited by calcium depletion. Unlike other tissues, placental uptake of valine and leucine exhibited both sodium-dependent and sodium-independent pathways. Both pathways were modestly sensitive to tissue calcium depletion. Finally, phenylalanine uptake was totally sodium dependent and calcium insensitive. The findings imply that calcium sensitivity, as well as tissue specificity, may be important parameters in studies of amino acid transport.

Acknowledgement. The authors gratefully acknowledge the cooperation of Ms. Sue Stross and her staff in the Delivery Room.

\section{REFERENCES}

1. Enders RH, Judd RM, Donohue TM, Smith CH 1976 Placental amino acid uptake. III. Transport systems for neutral amino acids. Am J Physiol 230:706-710

2. Christensen HN 1975 Biological Transport, 2nd ed. WA Benjamin Inc, Reading, MA

3 Oxender DL, Christensen HN 1963 Distinct mediating systems for the transport of neutral amino acids by the Erlich cell. J Biol Chem 238:3686-3699

4. Christensen HN, Cushing MK, Streicher JA 1949 Concentration of amino acids by excised diaphragm suspended in artificial media; maintenance of 
and inhibition of concentrating activity. Arch Biochem 23:96-105

5. Kelley DS, Evanson T, Potter VR 1980 Calcium-dependent hormonal regulation of amino acid transport and cyclic AMP accumulation in rat hepatocyte monolayer cultures. Proc Natl Acad Sci USA 77:5953-5957

6. Smith CH, Adcock III EW, Teasdale F, Meschia G, Battaglia FC 1973 Placental amino acid uptake: tissue preparation kinetics and preincubation effect. Am J Physiol 224:558-564

7. Fisher SE, Atkinson M. Van Thiel DH, Rosenblum E, David R, Holzman I 1981 Selective fetal malnutrition: the effect of ethanol and acetaldehyde upon in vitro uptake of alpha amino isobutyric acid by human placenta Life Sci 29:1283-1288

8. Smith CH, Depper R 1974 Placental amino acid uptake. II. Tissue preincubation, fluid distribution, and mechanisms of regulation. Pediatr Res 8:697703

9. Akedo H, Christensen HN 1962 Nature of insulin action on amino acid uptake by the isolated diaphragm. J Biol Chem 237:118-122

10. Segel IH 1975 Biochemical Calculations, 2nd ed. John Wiley \& Sons, New York

11. Assimacopoulos-Jeannet FD, Blackmore, PF, Exton JH 1977 Studies on $\alpha$ - adrenergic activation of hepatic glucose output. J Biol Chem 252:2662-2669

12. Yamamoto D, Yeh JV, Narahashi T 1985 Interactions of permeant cations with sodium channels of squid axon membrane. Biophys J 48:361-368

13. Ruedy J 1981 Verapamil. Clin Invest Med 4:129-147

14. Rasmussen H, Barrett PQ 1984 Calcium messenger system: an integrated view. Physiol Rev 64:938-984

15. Means AR, Tash JS, Chafouleas JG 1982 Physiological implications of the presence, distribution, and regulation of calmodulin in eukaryotic cells. Physiol Rev 62:1-38

16. Osborn M, Weber K 1980 Damage of cellular functions by trifluoperazine, a calmodulin-specific drug. Exp Cell Res 130:484-488

17. Vincenzi FF 1981 The pharmacology of calmodulin antagonism: a reappraisal. In: Kakiuchi S, Hidaka H, Means AR (eds) Calmodulin and Intracellular $\mathrm{Ca}^{++}$Receptors. Plenum Press, New York, pp $1-17$

18. Kuo JF, Anderson RGG, Wise BC, Mackerlova L, Salomonsson I, Brackett NL, Katoh N, Shoji M, Wrenn RW 1980 Calcium-dependent protein kinase: Widespread occurrence in various tissue and phyla of the animal kingdom and comparison of effects of phospholipid, calmodulin and trifluoperazine. Proc Natl Acad Sci USA 77:7039-7043. 